\title{
UPAYA MENGATASI KETERLAMBATAN MASUK KELAS MELALUI BIMBINGAN KELOMPOK DENGAN MENGGUNAKAN MEDIA SOSIODRAMA SISWA KELAS VII SEMESTER 1 SMP NEGERI 3 SITUBONDO TAHUN PELAJARAN 2019/2020
}

\author{
U.KHOLIYATI ${ }^{1}$ \\ ${ }^{1}$ SMP Negeri 3 Situbondo \\ Correspondence Email : kholiyatieku@g.mail.com
}

Received: March 11, $2021 \quad$ Revised: March 13, $2021 \quad$ Accepted: March 15, 2021

Selama ini peneliti sebagai guru BK di SMP Negeri 3 Situbondo hanya mencatat dan merekap peserta didik yang terlambat datang di sekolah dan memberi layanan konseling individual bagi peserta didik yang tergolong sering terlambat datang di sekolah. Mengingat pentingnya kedisiplinan datang tepat waktu pada kegiatan pembelajaran jam pertama maka perlu adanya kegiatan/tindakan yang mampu menyentuh kesadaran peserta didik untuk mentaati peraturan atau tata tertib yang berlaku disekolah, terutama disiplin datang tepat waktu di sekolah. Peneliti belum memberikan layanan bimbingan kelompok mengingat waktu dan perlunya persiapan yang lebih matang. Metode yang digunakan dalam penelitian ini adalah metode Penelitian PTKBK. Metode pengumpulan data yang digunakan adalah observasi, wawancara, dokumentasi dan tes. Analisis data deskriptif kualitatif. Berdasarkan permasalahan pada penelitian ini, maka upaya mengatasi keterlambatan masuk kelas sudah berkurang dari $40 \%$ menjadi $30 \%$ melalui bimbingan kelompok dengan menggunakan media sosiodrama di SMP Negeri 3 Situbondo.

Kata Kunci : Keterlambatan Masuk Kelas, Bimbingan Kelompok Dengan Menggunakan Media Sosiodrama 


\section{PENDAHULUAN}

Akhir-akhir ini sering kita lihat pandangan yang kurang menyenangkan di lingkungan SMP Negeri 3 Situbondo, terutama pada jam awal kegiatan pembelajaran. Pemandangan tersebut adalah masih banyaknya para peserta didik yang datang terlambat atau kurang disiplin datang tepat waktu disekolah. Keadaan ini menjadikan bahan pemikiran bagi para guru dan Pimpinan Sekolah untuk membuat mereka menjadi jera dan tidak akan datang terlambat lagi. Dari masukan Bapak Kepala Sekolah dan staf guru, dimulailah adanya hukuman bagi para peserta didik yang terlambat datang disekolah yaitu disuruh menyapu atau membersihkan halaman/taman sebelum diperbolehkan masuk ke kelas masing-masing.

Siswa yang terlambat datang disekolah tentunya akan mempengaruhi kegiatan belajar mengajar di kelas pada jam pertama, karena dalam pembelajaran klasikal, seorang guru membersihkan materi pelajaran kepada seluruh siswa dalam satu kelas secara bersama-sama, sehingga kedatangan siswa terlambat ke dalam kelas yang tengah berlangsung KBM mau tidak mau akan mengganggu proses pembelajaran baik mengganggu konsentrasi guru maupun menggangu konsentrasi peserta didik didalam kelas.

Dengan demikian perlu adanya tindakan untuk lebih mendisiplinkan para peserta didik datang tepat waktu di sekolah seperti yang telah tercantum pada tata tertib peserta didik SMP Negeri 3 Situbondo. Dalam perjalanan mendisiplin anak terlambat dengan hukuman membersihkan halaman sekolah nampaknya belum membuahkan hasil berarti, ditunjukkan dengan masih banyaknya para peserta didik yang datang di sekolah tidak tepat waktu atau terlambat.

Hal ini menandakan belum adanya kesadaran dari peserta didik untuk mentaati peraturan atau tata tertib yang berlaku di sekolah. Walaupun mereka sudah diberi sanksi atau hukuman tanpa adanya pemahaman dan kesadaran diri rasanya sulit untuk merubah sikap dan kebiasaan peserta didik untuk meningkatkan kedisiplinan datang tepat waktu diseluruh. Selama ini peneliti sebagai guru BK di SMP Negeri 3 Situbondo hanya mencatat dan merekap peserta didik yang terlambat datang di sekolah dan memberi layanan konseling individual bagi peserta didik yang tergolong sering terlambat datang di sekolah.

Mengingat pentingnya kedisiplinan datang tepat waktu pada kegiatan pembelajaran jam pertama maka perlu adanya kegiatan/tindakan yang mampu menyentuh kesadaran peserta didik untuk mentaati peraturan atau tata tertib yang berlaku disekolah, terutama disiplin datang tepat waktu di sekolah. Peneliti belum memberikan layanan bimbingan kelompok mengingat waktu dan perlunya persiapan yang lebih matang.

Dengan adanya peningkatan kedisiplinan datang tepat waktu di sekolah bagi para peserta didik diharapkan dapat seiring dengan peningkatan prestasi akademik yang akan menjunjung nama 
baik SMP Negeri 3 Situbondo. Keberhasilan peningkatan prestasi akademik suatu sekolah sangat tergantung kepada keinginan luhur dan kebersamaan dan seluruh elemen sekolah yang terkait dengan dukungan fasilitas sarana dan prasarana yang memadai. Peserta didik sebagai input atau sasaran dalam dunia pendidikan memiliki potensi dan kepribadian yang unik.

Prayitno (2004:1) menjelaskan bahwa layanan bimbingan kelompok merupakan proses pemberian informasi dan bantuan pada sekelompok orang dengan memanfaatkan dinamika kelompok guna mencapai suatu tujuan tertentu. Layanan bimbingan kelompok yang diberikan dalam suasana kelompok selain itu juga bisa dijadikan media penyampaian informasi sekaligus juga bisa membantu siswa menyusun rencana dalam membuat keputusan yang tepat sehingga diharapkan berdampak positif bagi siswa yang nantinya dapat mengubah perilaku yang menyimpang. Selain itu apabila dinamika kelompok dapat terwujud dengan baik, maka anggota kelompok saling menolong, menerima dan berempati dengan tulus. Sedangkan Wibowo (2005:31) menjelaskan bimbingan kelompok merupakan suatu proses intervensi yang bersifat membantu individu untuk meningkatkan pemahaman tentang diri sendiri dan hubungannya dengan orang lain.

Berdasarkan pengertian tersebut di atas, maka dapat disimpulkan bahwa layanan bimbingan kelompok merupakan layanan bimbingan yang dilaksanakan di dalam suasana kelompok. Pada pelaksanaan bimbingan kelompok ada konselor, yaitu Konselor, dan anggota kelompok yaitu klien (yang jumlahnya lebih dari satu orang). Terjadi hubungan konseling dalam suasana hangat, terbuka, permisif, dan penuh keakraban. Adanya pengungkapan dan pemahaman masalah klien, penelusuran sebab-sebab timbulnya masalah (jika perlu dengan menerapkan metode-metode khusus), kegiatan evaluasi dan tindak lanjut.

Tahapan-tahapan layanan bimbingan kelompok menurut Prayitno (2004: 40) ada empat tahap yaitu tahap pembentukan, tahap peralihan, tahap pelaksanaan kegiatan, dan tahap pengakhiran kegiatan. Penggunaan tehnik dalam kegiatan bimbingan kelompok mempunyai banyak fungsi selain dapat lebih memfokuskan kegaiatan bimbingan kelompok terhadap tujuan yang ingin dicapai tetapi juga dapat membuat suasana yang terbangun dalam kegiatan bimbingan kelompok agar lebih bergairah dan tidak cepat membuat siswa jenuh mengikutinya, seperti yang dikemukakan oleh Romlah (2001:24) menjelaskan bahwa teknik bukan merupakan tujuan tetapi sebagai alat untuk mencapai tujuan. Pemilihan dan penggunaan masingmasing teknik tidak dapat lepas dari kepribadian konselor atau pemimpin kelompok. Salah satu teknik yang dapat diterapkan dalam layanan bimbingan kelompok adalah media sosiodrama.

Sosiodrama adalah metode pembelajaran bermain peran untuk memecahkan masalahmasalah yang berkaitan dengan fenomena sosial, permasalahan yang menyangkut hubungan antara manusia seperti masalah kenakalan remaja, narkoba, gambaran keluarga yang otoriter, dan lain 
sebagainya. Sosiodrama digunakan untuk memberikan pemahaman dan penghayatan akan masalahmasalah sosial serta mengembangkan kemampuan siswa untuk memecahkannya.

\section{METODE PENELITIAN}

Masalah nyata yang ditemukan di sekolah, khususnya pada guru kelas adalah belum optimalnya dalam menyusun RPP dan angket. Prosedur penelitiannya dilakukan secara klasikal. Satu siklus dimulai dari (1) perencanaan awal, (2) pelaksanaan, (3) observasi dan (4) refleksi.

1. Perencanaan

Yaitu membuat rencana perbaikan berdasarkan adanya masalah atau kondisi yang menuntut diperbaiki. Hal ini meliputi persiapan bahan-bahan yang diperlukan dalam tahap pelaksanaan, menentukan siapa (subyek penelitian dan teman berkolaborasi), kapan (jadwal pelaksanan), menyusun RPP dan angket dan tempat pelaksanaan.

2. Pelaksanaan (Action)

Yaitu melakukan tindakan substantif penelitian melalui intervensi skala kecil guna memperbaiki kondisi yang diteliti.

3. Observasi (Observation)

Yaitu kegiatan mengamati, mengenali sambil mendokumentasikan (mencatat dan merekam) terhadap proses, hasil, pengaruh dan masalah baru yang mungkin saja muncul selama proses pelaksanaan tindakan. Dalam hal ini menggunakan angket untuk mengetahui aspek psikologi siswa dengan beberapa pertanyaan dengan menggunakan skala likers.

4. Refleksi (Reflection)

Dengan demikian, berdasarkan hasil tindakan atau pengalaman pada siklus pertama peneliti akan kembali melakukan langkah perencanaan, pelaksanaan, observasi dan refleksi pada siklus kedua, dan seterusnya. Jika digambarkan, siklus kerja PTBK adalah sebagai berikut:

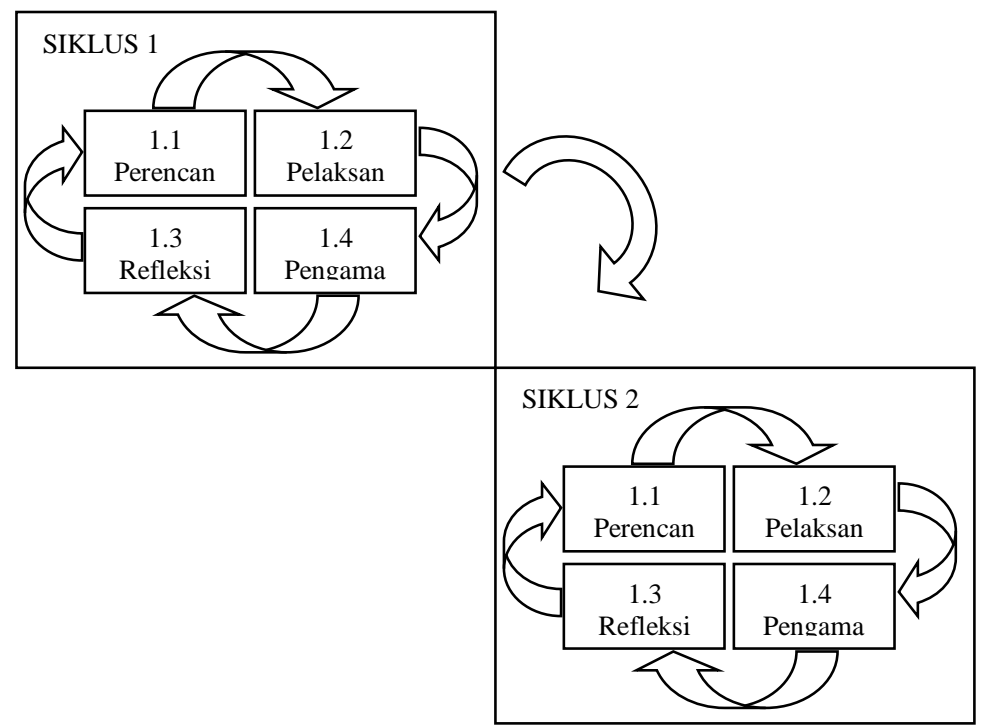

66|J UR R A L I K A V O L 9 No. 1 J U N I 20021 


\section{INDIKATOR KEBERHASILAN DAN SIKLUS}

Indikator keberhasilan merupakan pencatatan hasil penelitian yang mencakup segala peristiwa, fakta, keterangan, dan angka yang dapat dijadikan sebagai bahan untuk menyusun informasi yang diperlakukan untuk maksud tertentu, sumber datanya yaitu siswa. Skala psikologi(Azwar,juga 20 digunakan saat post test, data post test digunakan untuk mengetahui apakah ada peningkatan perilaku asertif yang dialami siswa sebelum dan sesudah diberikan treatment.

Berbeda dengan penelitian eksperimen, penelitian tindakan bukan hanya mengetes sebuah perlakuan tetapi terlebih dahulu peneliti sudah mempunyai keyakinan akan ampuhnya suatu perlakuan. Kemmis dan Mc Taggart (dalam Sukardi, 2008: 210) menyatakan bahwa penelitian tindakan merupakan cara suatu kelompok atau seseorang dalam mengorganisasi suatu kondisi sehingga dapat mempelajari pengalaman dan membuat pengalaman dapat diakses oleh orang lain. Setiap satu siklus terdiri dari empat tahap yaitu tahap perencanaan, pelaksanaan, observasi, dan refleksi. Untuk lebih jelasnya dapat diuraikan pada gambar berikut ini :
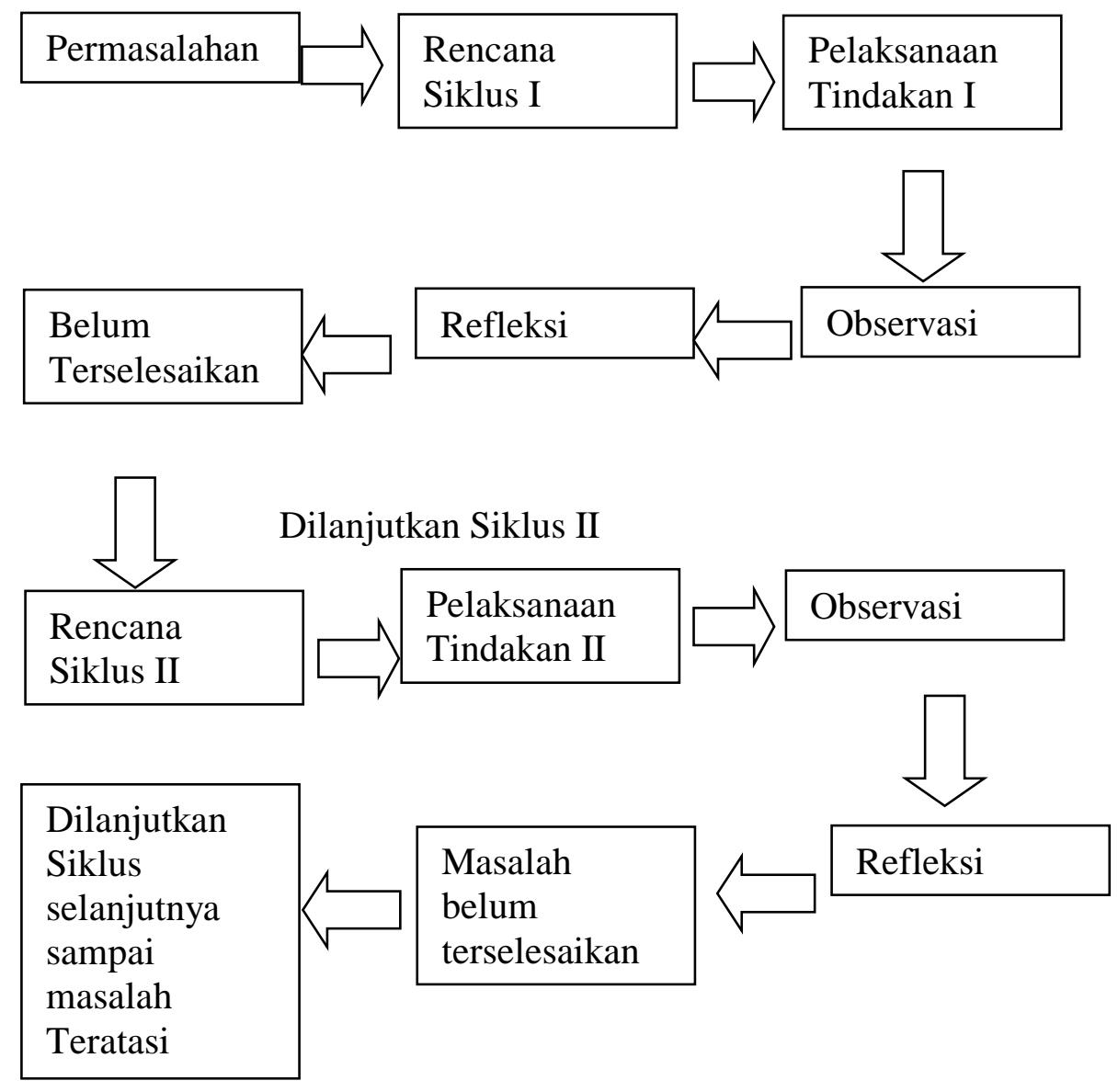
Adapun penjelasan dari siklus tersebut adalah sebagai berikut :

\section{Perencanaan}

Perencanaan merupakan serangkaian tindakan terencana untuk mencapai tujuan tindakan yang diharapkan.Pada penelitian ini perencanaan tindakan meliputi kegiatan persiapan sebelum pelaksanaan sosiodrama. Adapun kegiatan persiapan tersebut dapat dijabarkan sebagai berikut :

a. Peneliti membagi kelompok menjadi 3 kelompok dan masing-masing kelompok terdiri dari 6 orang anggota kelompok.

b. Peneliti menunjuk ketua dari tiap-tiap kelompok untuk mengkoordinasi anggota kelompok.

c. Peneliti menetapkan skenario drama yang akan ditampilkan untuk masingmasing kelompok kepada masing-masing ketua.

d. Masing-masing ketua memberikan penjelasan mengenai alur jalannya drama sekaligus melakukan pembagian peran sesuai dengan tokoh yang ada di dalam naskah drama.

e. Setelah masing-masing kelompok memahami materi drama yang dijelaskan oleh tutor maka, tutor diminta untuk menentukan waktu latihan dari masingmasing kelompok sebelum kegiatan pementasan drama.

f. Peneliti menentukan waktu dan tempat pementasan drama.

\section{Tindakan}

Tindakan dalam penelitian tindakan merupakan kegiatan praktis yang terencana.Pada penelitian ini, tindakan yang diterapkan yaitu melaksanakan pementasan sosiodrama untuk meningkatkan tata krama pergaulan di sekolah. Adapun kegiatannya adalah sebagai berikut :

a. Masing-masing ketua mengkoordinasi kelompok yang diampu untuk mempersiapkan diri.

b. Peneliti memberikan Ice breaking pada semua peserta sosiodrama serta memberikan uraian singkat mengenai jalannya kegiatan sosiodrama

c. Peneliti melakukan undian untuk menentukan nomor urut tampil dari masingmasing kelompok yang akan mementaskan drama.

d. Kelompok yang maju untuk mementaskan drama ditetapkan sebagai kelompok pemain, sementara kelompok yang lain sebagai kelompok penonton. 
e. Peneliti, dan guru BK bersama-sama mengamati jalannya sosiodrama untukmengetahui reaksi dan perhatian dari siswa yang mempunyai masalah keterlambatan masuk kelas .

\section{Observasi}

Observasi pada penelitian tindakan memiliki fungsi mendokumentasikan implikasi tindakan yang diberikan kepada subjek.Observasi pada penelitian ini yaitu mengamati tingkah laku yang dihasilkan pada saat pelaksanaan sosiodrama maupun setelah pelaksanaan sosiodrama. Selama pelaksanaan sosiodrama kegiatan yang dilakukan adalah sebagai berikut :

a. Setiap penampilan drama dari tiap-tiap kelompok selesai ditampilkan, peneliti melakukan diskusi dengan kelompok penonton untuk memberikan evaluasi terhadap jalannya drama yang baru saja selesai dipentaskan.

b. Peneliti meminta kelompok penonton untuk mengomentari pementasan drama yang baru saja selesai dipentaskan.

c. Peneliti memberikan tambahan penjelasan kepada semua peserta layanan mengenai makna drama yang telah ditampilkan untuk dapat dimaknai dan diaplikasikan dalam kehidupan sehari-hari.

d. Peneliti membuat kesimpulan dari pelaksanaan sosiodrama.

e. Peneliti mengakhiri kegiatan sosiodrama.

Setelah pelaksanaan sosiodrama selesai kemudian dilakukan observasi untuk mengetahui perubahan kemampuan siswa dalam menerapkan tata kramapergaulan di sekolah setelah diberi layanan bimbingan kelompok dengan teknik sosiodrama.Pelaksanaan kegiatan Observasi melibatkan guru BK, serta teman-teman dari subyek penelitian.

\section{Refleksi}

Refleksi merupakan sarana untuk melakukan pengkajian kembali tindakan yang telah dilakukan terhadap subjek penelitian.Pada penelitian tindakan ini, langkah refleksi digunakan untuk mengkaji keefektifan bimbingan kelompok teknik sosiodrama dalam meningkatkan tata kram pergaulan di sekolah. Adapun langkah refleksi pada penelitian ini dapat dijelaskan sebagai berikut :

a. Peneliti mengaanalisis hasil observasi setelah pelaksanaan sosiodrama.

b. Apabila belum dicapai target peningkatan seperti yang telah ditetapkan maka dilanjutkan kegiatan sosiodrama untuk siklus yang kedua sampai terget tercapai.

Apabila sudah memenuhi target / kriteria maka penelitian dinyatakan berhasil, artinya bimbingan kelompok teknik sosiodrama dinyatakan dapat mengatasi masalah keterlambatan masuk kelas. 
Untuk menguji hipotesa yang telah dikemukakan di depan dan untuk mendapatkan kesimpulan yang benar maka data yang terkumpul harus dianalisis. Adapun cara menganalisa dan mengolahnya sangatlah tergantung dari jenis datanya. Analisis data adalah cara pengolahan data yang diperoleh sehingga dapat diartikan makna dari data tersebut. Pada penelitian ini data yang dianalisis adalah data dari observasi. Selanjutnya langkah yang dilakukan adalah melakukan analisis terhadap perubahan yang terjadi di setiap siklus. Analisis tersebut dibagi menjadi dua, yaitu analisis persentase dan analisis klinis. Kedua analisis tersebut dapat di jelaskan sebagai berikut :

\section{Analisis Persentase}

Analisis persentase digunakan untuk mengetahui perubahan perilaku subjek. Perubahan perilaku tersebut dapat diperoleh dengan rumus sebagai berikut:

Presentage change $=\frac{\text { Post rate }- \text { base rate }}{\text { base rate }} \times 100 \%$

Keterangan :

Percentage change : prosentase perubahan tingkah laku

Base rate : penilaian dasar sebelum treatment

Post rate : penilaian akhir setelah pemberian treatment

(D.L Godwin dan T. J Coates, 1976:57)

Rumus tersebut digunakan untuk mengetahui persentase perubahan perilaku subjek antara sebelum dan sesudah diberikan tindakan, sehingga dapat diketahui tingkat keberhasilan tindakan yang telah diberikan. Jika penilaian akhir menyatakan bahwa setelah diberikan treatment berupa layanan bimbingan kelompok melalui teknik sosiodrama dapat mencapai 50\% dari penilaian semula sebelum diberikan treatment, maka penelitian dikatakan berhasil atau dengan kata lain bahwa pelaksanaan layanan bimbingan kelompok dengan teknik sosiodrama untuk mengatasi keterlambatan masuk kelas di sekolah dinyatakan berhasil. Namun apabila kurang dari 50\% setelah pemberian treatment maka layanan bimbingan kelompok dengan teknik sosiodrama untuk mengatasi keterlambatan masuk kelas di sekolah tersebut dianggap kurang efektif untuk mengatasi keterlambatan masuk kelas di sekolah pada siswa kelas VII SMP Negeri 3 Situbondo

\section{Analisis Klinis}

Analisis klinis dibagi menjadi dua yaitu analisis sosial dan analisis subjek. Analisis sosial dilakukan dengan membandingkan perilaku subjek terhadap pencapaian tugas-tugas perkembangan. Analisissubjek dilakukan dengan bertanya pada orang tua, teman, atau guru dan wali kelas mengenai perubahan perilaku yang ditunjukkan oleh subjek penelitian. Pada penelitian ini penganalisisan data yang diperoleh menggunakan dua cara yaitu analisis persentase dan analisis klinis. Dari analisis ini diketahui perubahan pada setiap siklus. 


\section{Indikator Kinerja Penelitian}

Bagian ini merupakan tolak ukur keberhasilan tindakan yang akan dilakukan sebagai dasar penilaian berhasil atau gagalnya tindakan yang dilaksanakan melalui penelitian tindakan. Berdasarkan pengertian tersebut, maka indikator keberhasilan tindakan pada penelitian ini yaitu: tindakan dinyatakan berhasil dan efektif apabila subjek penelitian dapat mengatasi keterlambatan masuk kelas dengan prosentase penurunan sebesar 50\%. Pada penelitian ini indikator pencapaian yang diharapkan muncul sebagai hasil tindakan adalah berubahnya perilaku siswa yang memiliki keterlambatan masuk kelas tidak baik menjadi keterlambatan masuk kelas baik pada keempat siswa sebagai subjek penelitian.

\section{HASIL PENELITIAN DAN PEMBAHASAN}

Berdasarkan hasil observasi dan wawancara yang telah dilakukan, terdapat 10 siswa yang teridentifikasi mempunyai keterlambatan di sekolah yang rendah. Siswa tersebut merupakan siswa kelas VII . Ketentuan untuk menentukan siswa yang mempunyai tingkat tata krama yang rendah adalah dengan menggunakan beberapa kriteria yang telah ditetapkan sebelumnya oleh peneliti. Hal tersebut dilakukan dengan tujuan untuk memastikan siswa yang mendapatkan prioritas utama untuk diberikan layanan bimbingan kelompok dengan teknik sosiodrama.

Sesuai dengan hasil observasi yang telah dilakukan terdapat siswa yang kurang mempunyai keterlambatan disekolah. Siswa tersebut bukan semua siswa kelas VII. SMP Negeri 3 Situbondo memiliki jumlah siswa sebanyak 129 siswa. Subjek penelitian ini bukan semua siswa kelas VII SMP Negeri 3 Situbondo, melainkan hanya siswa yang memiliki tingkat tata krama kurang baik dalam pergaulan di sekolah berdasarkan hasil wawancara dengan Guru BK dan salah satu guru mata pelajaran yang juga sebagai wali kelas di kelas VII SMP Negeri 3 Situbondo dan dilanjutkan dengan pengamatan (observasi) untuk memastikan apakah benar siswa tersebut memiliki tata krama yang kurang baik. Berdasarkan obsevasi yang dilakukan oleh guru BK pada kondisi awal sebelum penelitian, perilaku keterlambatan masuk sekolah siswa pada subyek penelitian 10 siswa dapat dilihat pada Tabel sebagai berikut:

Adapun perbandingan hasil pelaksanaan layanan bimbingan kelompok untuk meningkatkan keterlambatan masuk sekolah pada kondisi awal, siklus I dan siklus II dapat dilihat Tabel berikut: Tabel Hasil Observasi Keterlambatan Masuk Sekolah (Prasiklus, Siklus I dan Siklus II)

\begin{tabular}{|c|l|c|c|c|}
\hline No & Nama & Prasiklus & Siklus I & Siklus II \\
\hline 1 & A & 67 & 79 & 89 \\
\hline 2 & B & 56 & 67 & 89 \\
\hline 3 & C & 44 & 67 & 78 \\
\hline 4 & D & 33 & 33 & 33 \\
\hline
\end{tabular}

71 J U R N A L I K A V O L 9 No. 1 J U N I 20021 


\begin{tabular}{|c|l|c|c|c|}
\hline 5 & $\mathrm{E}$ & 33 & 56 & 56 \\
\hline 6 & $\mathrm{~F}$ & 56 & 78 & 78 \\
\hline 7 & $\mathrm{G}$ & 67 & 67 & 89 \\
\hline 8 & $\mathrm{H}$ & 44 & 44 & 56 \\
\hline 9 & $\mathrm{I}$ & 44 & 67 & 78 \\
\hline 10 & $\mathrm{~J}$ & 33 & 33 & 56 \\
\hline 11 & $\mathrm{~K}$ & 67 & 89 & 89 \\
\hline 12 & $\mathrm{~L}$ & 56 & 67 & 89 \\
\hline 13 & $\mathrm{M}$ & 44 & 67 & 78 \\
\hline 14 & $\mathrm{~N}$ & 33 & 33 & 33 \\
\hline 15 & $\mathrm{O}$ & 33 & 56 & 56 \\
\hline 16 & $\mathrm{P}$ & 56 & 78 & 78 \\
\hline 17 & $\mathrm{Q}$ & 67 & 67 & 89 \\
\hline 18 & $\mathrm{R}$ & 44 & 64 & 86 \\
\hline 19 & $\mathrm{~S}$ & 44 & 67 & 78 \\
\hline 20 & $\mathrm{~T}$ & 63 & 73 & 86 \\
\hline & & $48 \%$ & $60 \%$ & $70 \%$ \\
\hline
\end{tabular}

\section{Refleksi}

Refleksi dilakukan dengan menggunakan hasil observasi dan menggunakan wawancara kepada siswa. Berdasarkan hasil pengamatan dan wawancara kepada siswa, catatan peneliti dan observasi pengamat diperoleh peneliti mampu memotivasi siswa agar mampu berperilaku disiplin, tema yang diberikan menjadi menarik karena tema yang dipilih adalah yang mereka inginkan, itu membuat siswa menjadi tertarik mengikuti kegiatan bimbingan kelompok, serta anggota kelompok lain memberikan penilaian terhadap teman-temannya melakukan peran dalam sosiodrama. Berdasarkan hasil observasi dan wawancara yang sudah dilakukan peneliti maka, dapat dikemukakan bahwa terdapat perubahan perilaku siswa dalammenerapkan sosiodrama di sekolah. Perubahan tersebut dilihat dari perubahan yang ditunjukkan oleh masing-masing siswa yang mengikuti kegiatan sosiodrama. Berdasarkan target yang telah ditetapkan sebelumnya sebagai indikator keberhasilan yaitu masing-masing siswa harus mampu mengalami perubahan peningkatan kemampuan menerapkan sosiodrama di sekolah minimal sebesar $60 \%$ maka, prosentase perubahan tersebut sudah dapat mencapai target karena semua siswa sudah dapat mencapai perubahan minimal $70 \%$ layanan bimbingan kelompok teknik sosiodrama pada siklus II dinyatakan berhasil.

\section{PEMBAHASAN}

Tindakan pada masing-masing siklus sudah dilaksanakan. Melalui hasil analisis dan refeleksi pada tiap sikus diketahui bahwa untuk meningkatkan kemampuan siswa dalam menerapkan sosiodrama di sekolah dibutuhkan dua siklus yaitu siklus I dan siklus II. Kedua siklus tersebut menunjukkan capaian hasil perubahan yang berbeda-beda. Untuk memperjelas hasil 72 J U R N A L I K A V O L 9 No . 1 J U N I 2002 
tindakan tiap siklus maka perlu dibuat perbandingan hasil tindakan tiap siklus. Perubahan di atas sesuai dengan teori yang di kemukakan oleh Nana Sukmadinata, (1983: 55) "bahwa Sosiodrama selain mempunyai nilai seni, juga mempunyai nilai-nilai terapi”. Hal ini terbukti bahwa setelah diberi layanan bimbingan kelompok dengan teknik sosiodrama "A", “ M", "R", dan "T" mengalami peningkatan sosiodrama di sekolah manjadi lebih baik. Pribadi seorang individu berkembang melalui proses bagaimana ia melakukan peranaannya dalam melakukan interaksi dengan orang lain, dan dari status yang ia terima dalam menghadapi situasi sosial yang berbedabeda. Seorang individu mempunyai hubungan sosial yang baik karena ia mengerti peranannya dan mengerti peranan oraag lain serta memberikan respon yang baik pada yang lain.

Penggunaan bimbingan kelompok dengan teknik informasi mampu meningkatkan tata krama sedangkan dalam penelitian ini bimbingan kelompok dengan teknik sosiodrama terbukti efektif untuk meningkatkan tata krama pergaulan di sekolah. Berdasarkan hasil penelitian di atas terbukti bahwa teknik sosiodrama efektif untuk meningkatkan tata krama pergaulan di sekolah. Sehubung dengan penelitian ini dapat dikemukakan implikasi hasil penelitian adalah sebagai berikut:

1. Teknik sosiodrama dapat memberikan alternatif pemecahan masalah dalam meningkatkan tata krama pergaulan di sekolah siswa sehingga bagi guru BK dapat memberikan variasi layanan.

2. Melalui sosiodrama terjadi peningkatan tata krama pergaulan di sekolah siswa,

3. peningkatan tersebut membuat siswa untuk dapat lebih mudah diterima dalam lingkungan pergaulan di sekolah pada khususunya.

Adanya keberhasilan penggunaan teknik sosiodrama maka skenario drama yang digunakan pada penelitian ini dapat digunakan konselor sekolah sebagai contoh skenario sosiodrama untuk meningkatkan tata krama pergaulan di sekolah.

\section{KESIMPULAN}

Berdasarkan hasil pembahasan pada bab IV dapat disimpulkan bahwa upaya mengatasi keterlambatan masuk kelas sudah berkurang dari $40 \%$ menjadi 30\% melalui bimbingan kelompok dengan menggunakan media sosiodrama Siswa Kelas VII Semester 1 di SMP Negeri 3 Situbondo.

Sesuai dengan simpulan dan implikasi hasil penelitian, maka ada beberapa saran yang dapat dipergunakan sebagai pertimbangan.

1. Kepala Sekolah

Kepala sekolah hendaknya memberikan masukan kepada guru pembimbing untuk menerapkan secara rutin teknik sosiodma sehingga lebih variatif dalam memberikan layanan bimbingan dan konseling untuk mengatasi kasus dan juga dapat mengetahui bakat-bakat serta minat pada diri anak yang belum terungkap, misalnya dalam bakat dalam bidang bermain peran peran. 


\section{Bagi Siswa}

Siswa diharapkan lebih mempelajari fenomena untuk meningkatkan kesadaran untuk mengembangkan kemampuan yang ada di dalam dirinya, supaya menjadi pribadi yang unggul, bukan hanya pada pembelajaran tetapi mempunyai softskill yang dapat menjadi bekal untuk menuju kesuksesan.

3. Kepala sekolah dan Guru

Kepala sekolah hendaknya memberikan masukan kepada guru agar lebihmemperhatikan tata krama pergaulan di sekolah para siswa yang sudah mulai luntur. 


\section{DAFTAR PUSTAKA}

Ahmadi, 2011. Strategi Pembelajaran Sekolah Terpadu. Jakarta: Prestasi Pustaka Publiaher

Arikunto, 2006. Prosedur Penelitian Suatu Pendekatan Praktik, Ed Revisi VI,. Jakarta: PT Rineka Cipta,

Arikunto, S., Suhardjono dan Supardi. 2008. Penelitian Tindakan Kelas: Panduan Untuk Guru. Jakarta: Rineka Cipta.

Azwar, 2007. Metode Penelitian. Yogyakarta: Pustaka Pelajar

Corey, G. 1995. Theory and Practice of Group Counseling. Canada :Brooks/Cole.

Cormier, W. H. dan Cormier L. S. 1985. Interviewing Strategies For Helpers Fundamental Skill and Behavioral Interventions. 2 ed. Monterey. California: Publishing Company.

Depdiknas, 2008. Kurikulum Tingkat Satuan Pendidikan. Jakarta: dikmenum. Depdiknas.

Ermananti, 1999. Dasar- Dasar Bimbingan dan Konseling. Jakarta : Rineka Cipta

Ervianto, 1998. Repetitive Scheduling Method. Civil and Environmental Engineering Department

Gunarsa, S. D. 1996. Konseling dan Psikoterapi. Jakarta: BPK Gunung Mulia.

Hallen, 2002. Bimbingan dan Konseling, Jakarta: Ciputat Pers

Depdiknas, 2007. Kamus Besar Bahasa Indonesia, Depdiknas

Levis dan Atherley, 1996. Delay Construction. Langford.

Marno dan M. Idris, 2008. Strategi \& Metode Pengajaran: Menciptakan Keterampilan Mengajar yang Efektif dan Edukatif. Yogyakarta: Ar-ruzz Media

McLeod, J. 2007. Pengantar Konseling Teori dan Studi Kasus. Jakarta: Prenanda Media Group.

Nana Sukmadinata, 1983. Landasan Psikologi Proses Pendidikan, Bandung: Remaja Rosda Karya

Depdikans, 2009. Panitia Pelaksana Pendidikan dan Latihan Profesi Guru.

Prayitno. 2004. Dasar-dasar Bimbingan dan Konseling. Depdikbud: Rineka Cipta.

Rahardjo, S. dan Gudnanto. 2011. Pemahaman Individu Pendekatan Non Test. Kudus:Nora Enterprise.

Rahman, 2003. Bimbingan dan Konseling Pola 17. Yogyakarta: UCY Press

Riduwan, 2011. Metode dan Teknik Menyusun Tesis. Bandung: Penerbit Alfabeta

Romlah, T. 2001. Teknik-Teknik Bimbingan dan Konseling Kelompok. Malang: Universitas Negeri Malang.

Sitti Hartinah, 2009. Konsep Dasar Bimbingan Kelompok, Bandung:P.T Reflika Aditama 
Sudjana, 2009. Penilaian Hasil Proses Belajar Mengajar. Bandung: PT Remaja Rosdakarya Sugiyono, 2007. Metode Penelitian Kuantitatif Kualitatif $R \&$ D. Bandung: Alfabeta

Sukardi, 2008. Penelitian Kualitatif-Naturalistik dalam Pendidikan. Yogyakarta : Usaha Keluarga

Sukmadinata, 2005. Landasan Psikologi Proses Pendidikan, Bandung: PT Rosda Karya.

Tatiek Romlah, 2001. Teori dan Praktek Bimbingan Kelompok. Malang: Universitas Negeri Malang.

Tohirin, 2007. Bimbingan Konseling di Sekolah dan Madrasah, Jakarta: Raja Grafindo Persada

Walgito, 2004. Bimbingan dan Penyuluhan Di sekolah. Yogyakarta: Andi Offset

Wibowo, M.E. 2005. Konseling Kelompok Perkembangan. Semarang: UNNES Press.

Wina, 2012. Strategi Pembelajaran Berorientasi Standar Proses Pendidikan. Jakarta: Kencana

Wingkel, 2004. Psikologi Pendidikan dan Evaluasi Belajar. Jakarta: PT. Gramedia Pustaka Utama 